Supporting Information

\title{
Bicyclic Chalcones as Mitotic Inhibitors for Overcoming Androgen Receptor-Independent and Multidrug Resistant Prostate Cancer
}

\author{
Yohei Saito, ${ }^{\dagger}$ Atsushi Mizokami, ${ }^{\star}$ Sayaka Maeda,${ }^{\dagger}$ Kyoko Takahashi, ${ }^{\dagger}$ Kouji Izumi,${ }^{\star}$ \\ Masuo Goto ${ }^{\S}$ and Kyoko Nakagawa-Goto ${ }^{*}$, ,,
}

†School of Pharmaceutical Sciences, College of Medical, Pharmaceutical and Health Science, Kanazawa University, Kanazawa, 920-1192, Japan

Department of Integrative Cancer Therapy and Urology, School of Medical Sciences, Kanazawa University, Kanazawa, 920-1192, Japan

${ }^{\S}$ Chemical Biology and Medicinal Chemistry, Eshelman School of Pharmacy, University of North Carolina, Chapel Hill, North Carolina 27599, United States

\section{For Table of Contents Only}

Figures S1-S19. ${ }^{1} \mathrm{H}$ NMR and ${ }^{13} \mathrm{C}$ NMR spectra of compounds 3-5 and 9-15......S2-11 
Figure S1. ${ }^{1} \mathrm{H}$ NMR spectrum of compound $3\left(600 \mathrm{MHz}\right.$, in $\left.\mathrm{CDCl}_{3}\right)$

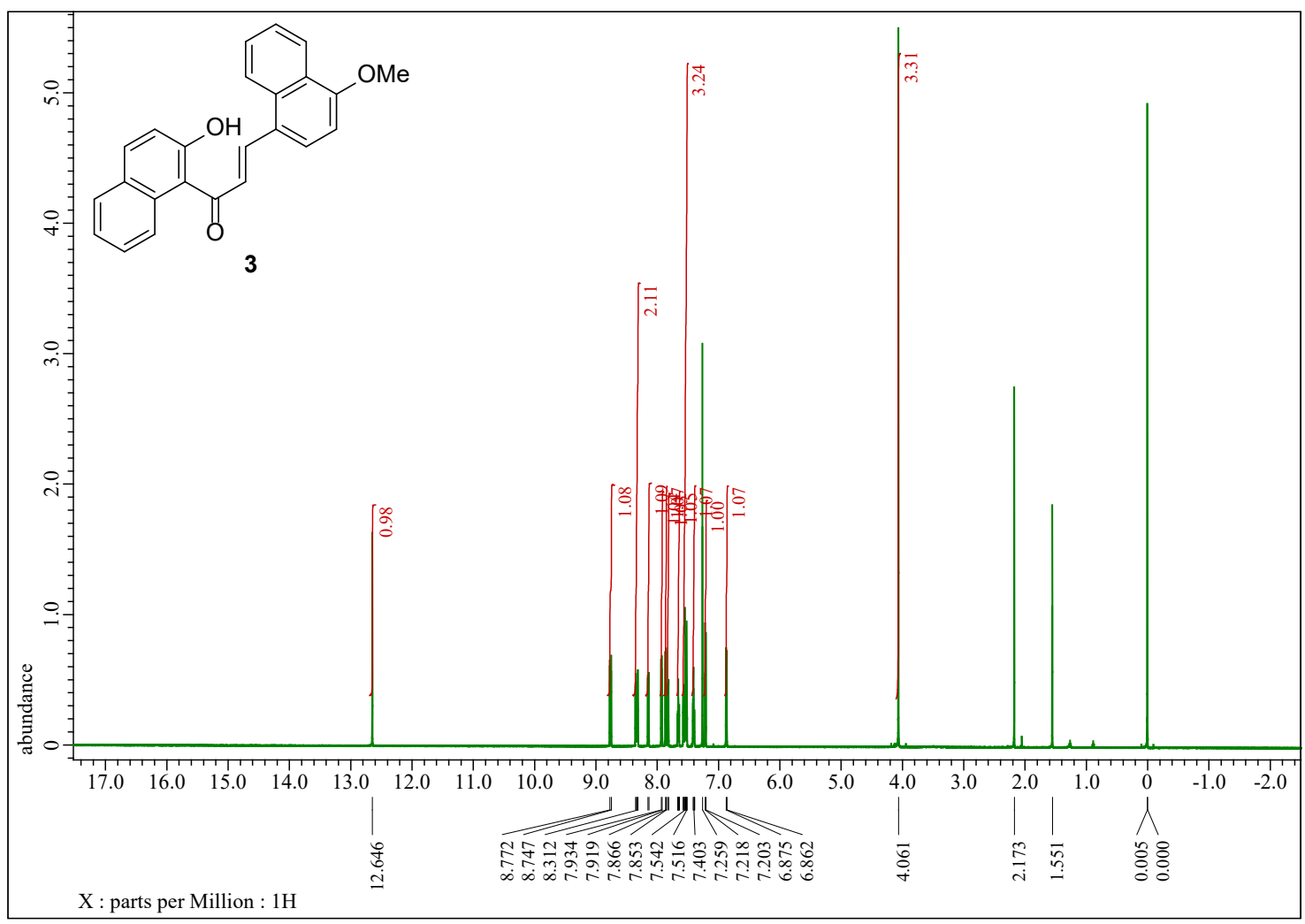

Figure S2. ${ }^{13} \mathrm{C}$ NMR spectrum of compound $3\left(150 \mathrm{MHz}\right.$, in $\left.\mathrm{CDCl}_{3}\right)$

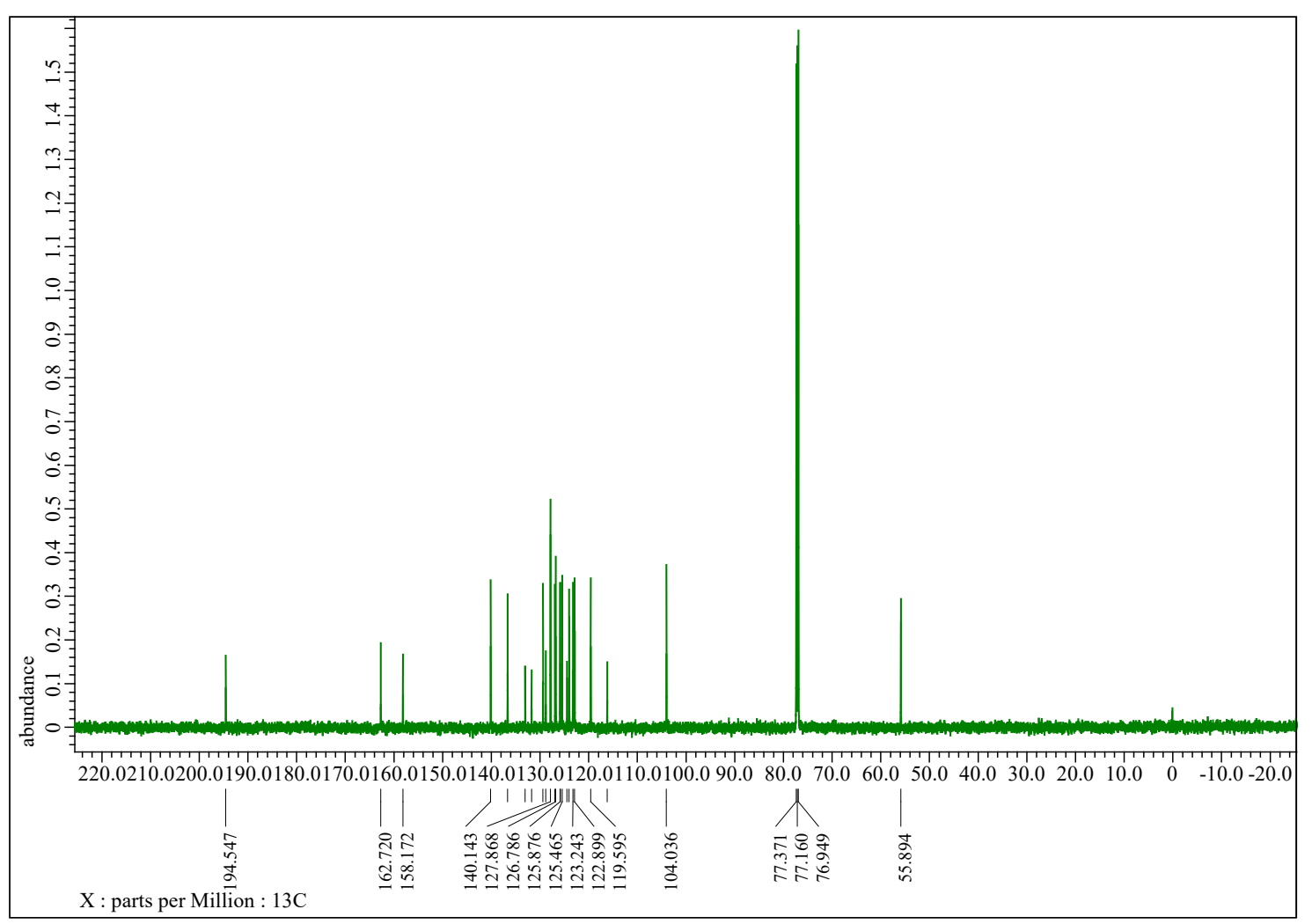


Figure S3. ${ }^{1} \mathrm{H}$ NMR spectrum of compound $4\left(600 \mathrm{MHz}\right.$, in $\left.\mathrm{CDCl}_{3}\right)$

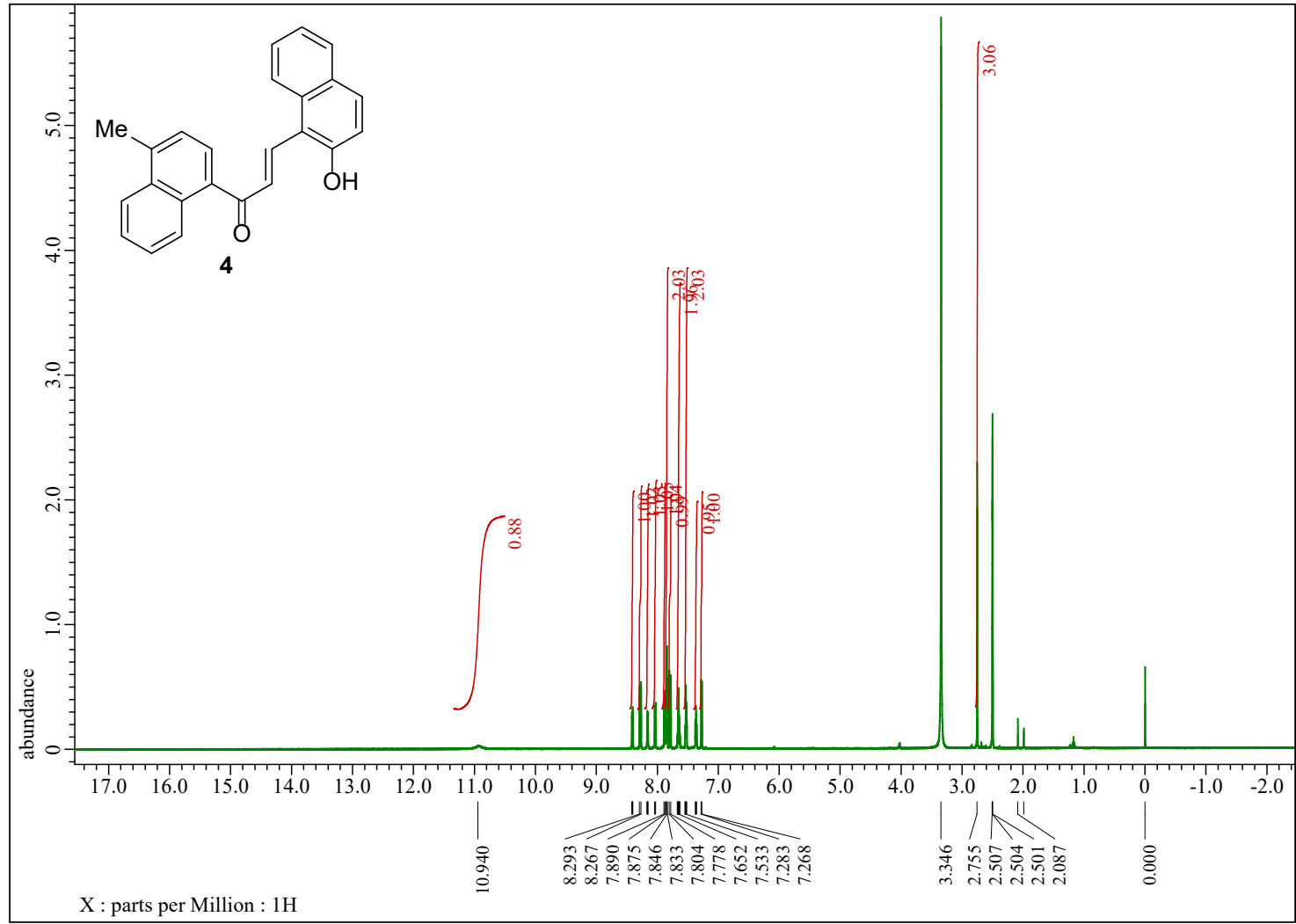

Figure S4. ${ }^{13} \mathrm{C}$ NMR spectrum of compound $4\left(150 \mathrm{MHz}\right.$, in $\left.\mathrm{CDCl}_{3}\right)$

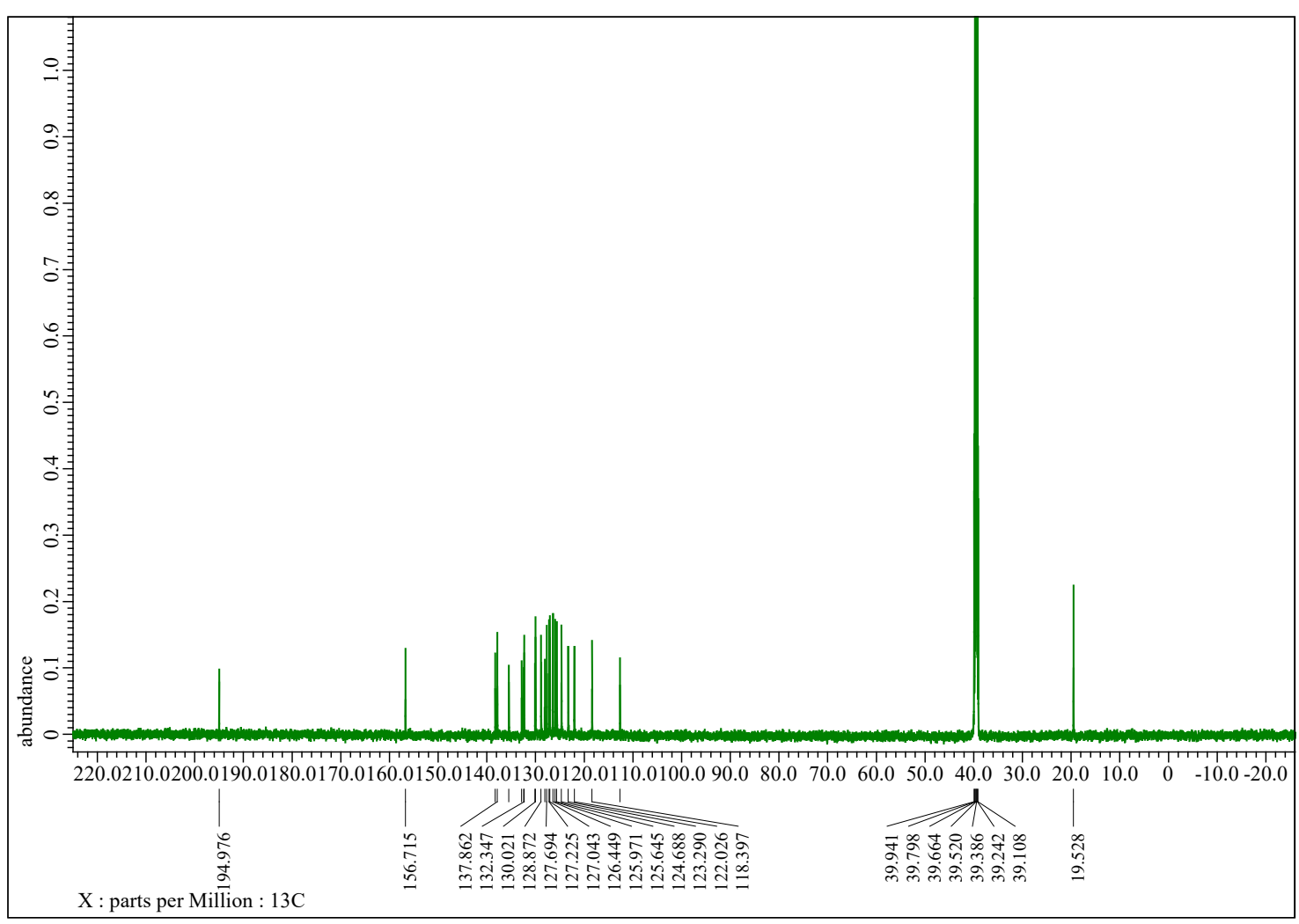


Figure S5. ${ }^{1} \mathrm{H}$ NMR spectrum of compound $5\left(600 \mathrm{MHz}\right.$, in $\left.\mathrm{CDCl}_{3}\right)$

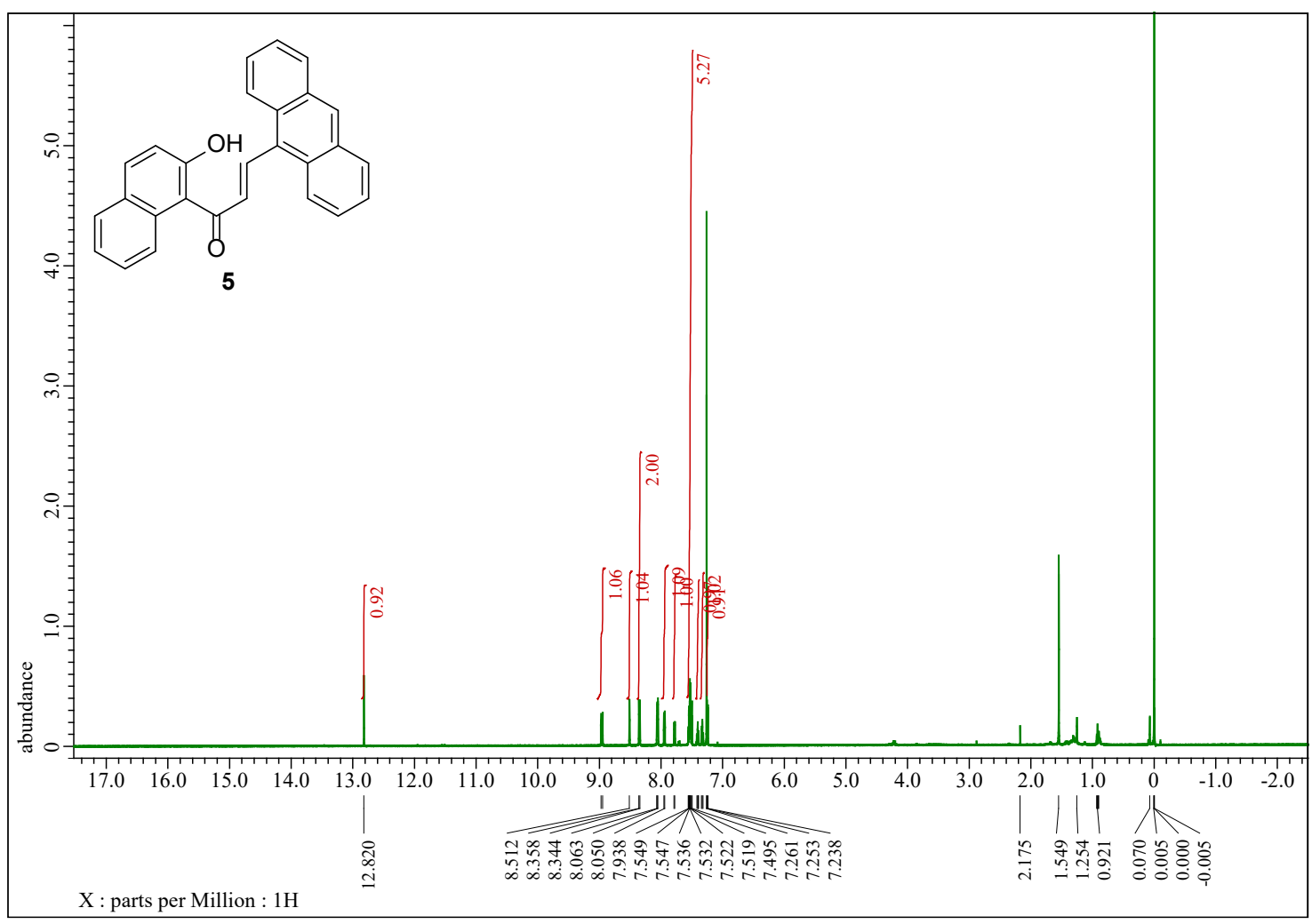

Figure S6. ${ }^{13} \mathrm{C}$ NMR spectrum of compound $5\left(150 \mathrm{MHz}\right.$, in $\left.\mathrm{CDCl}_{3}\right)$

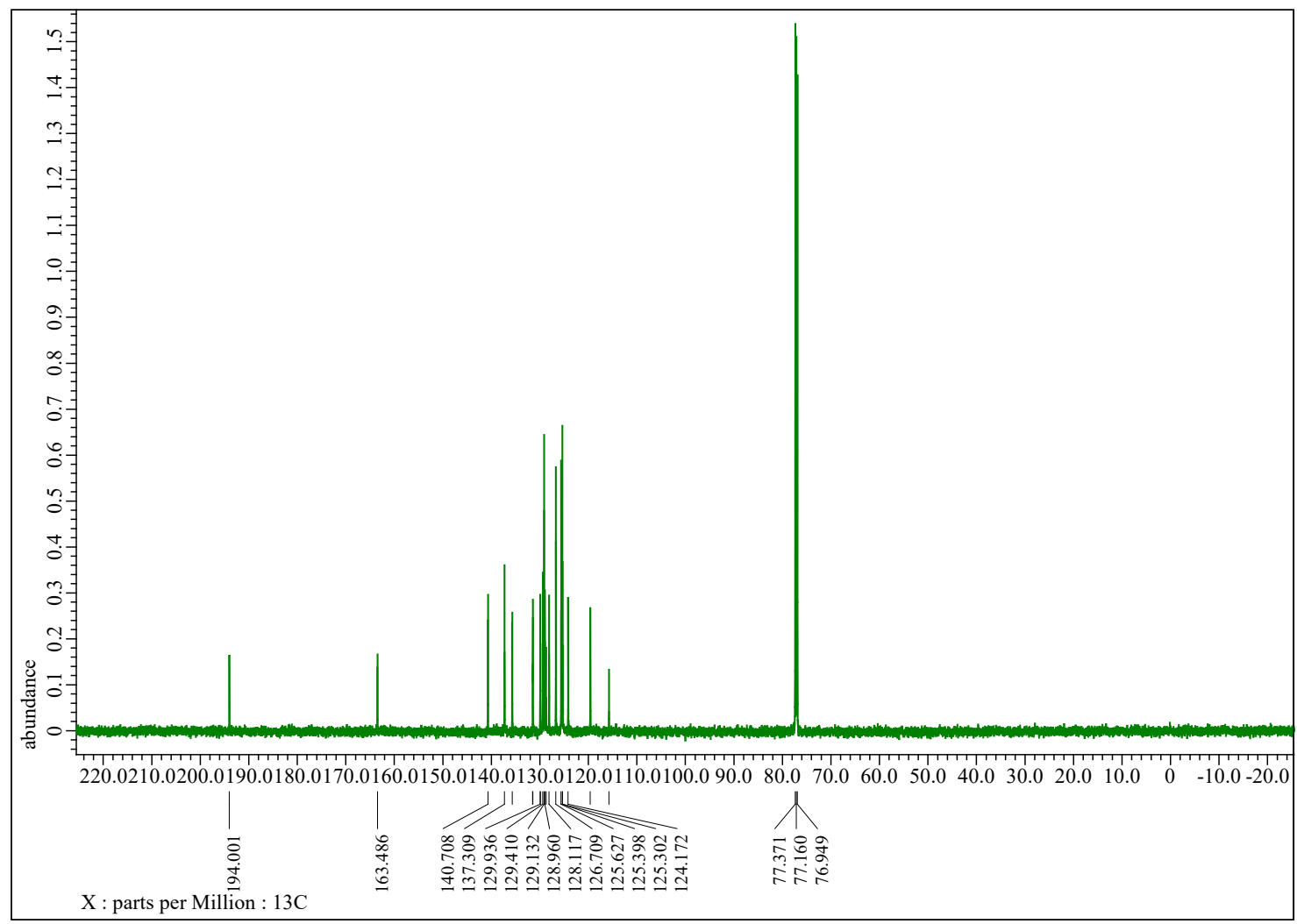


Figure S7. ${ }^{1} \mathrm{H}$ NMR spectrum of compound $9\left(400 \mathrm{MHz}\right.$, in $\left.\mathrm{CDCl}_{3}\right)$

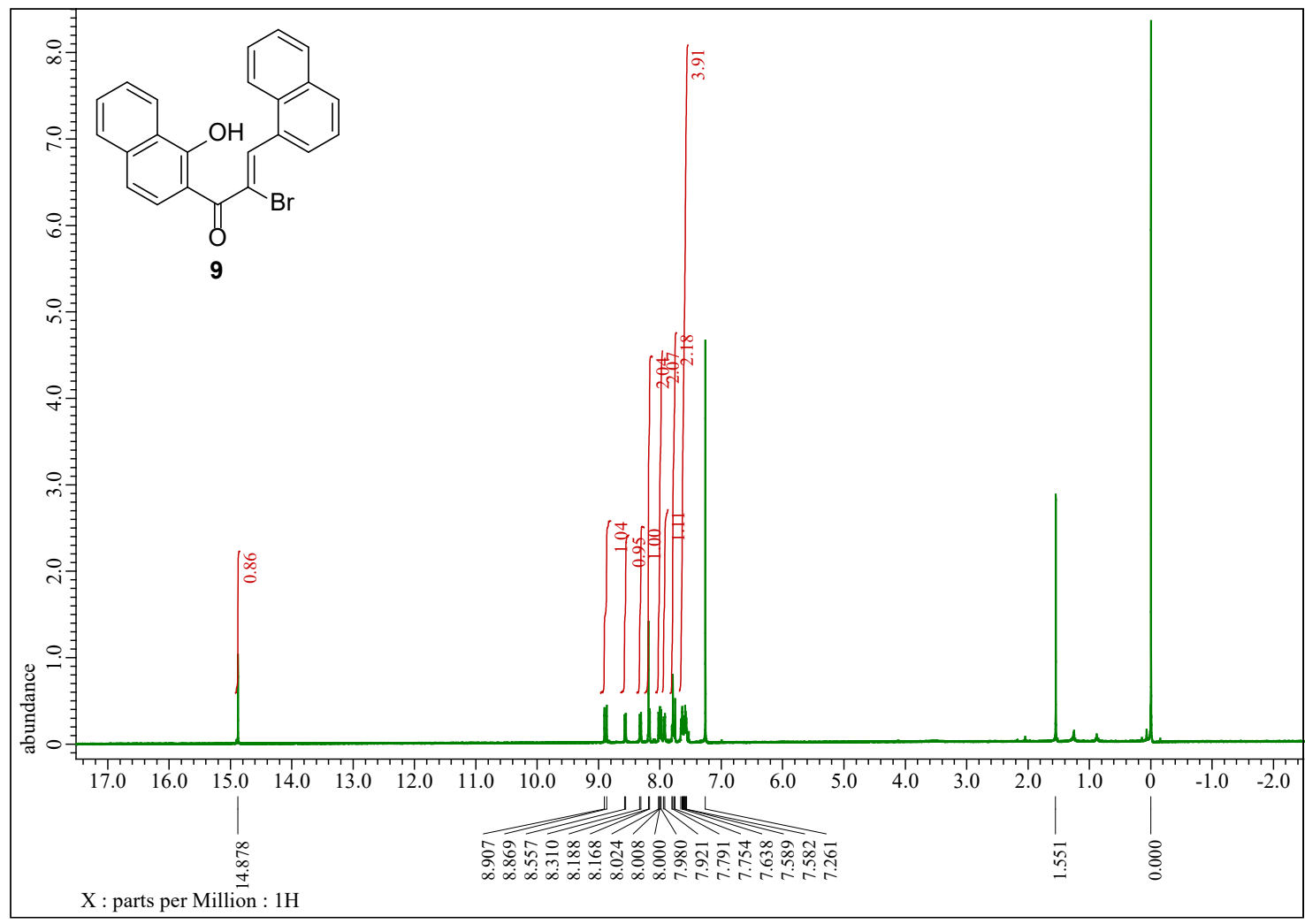

Figure S8. ${ }^{13} \mathrm{C}$ NMR spectrum of compound $9\left(150 \mathrm{MHz}\right.$, in $\left.\mathrm{CDCl}_{3}\right)$

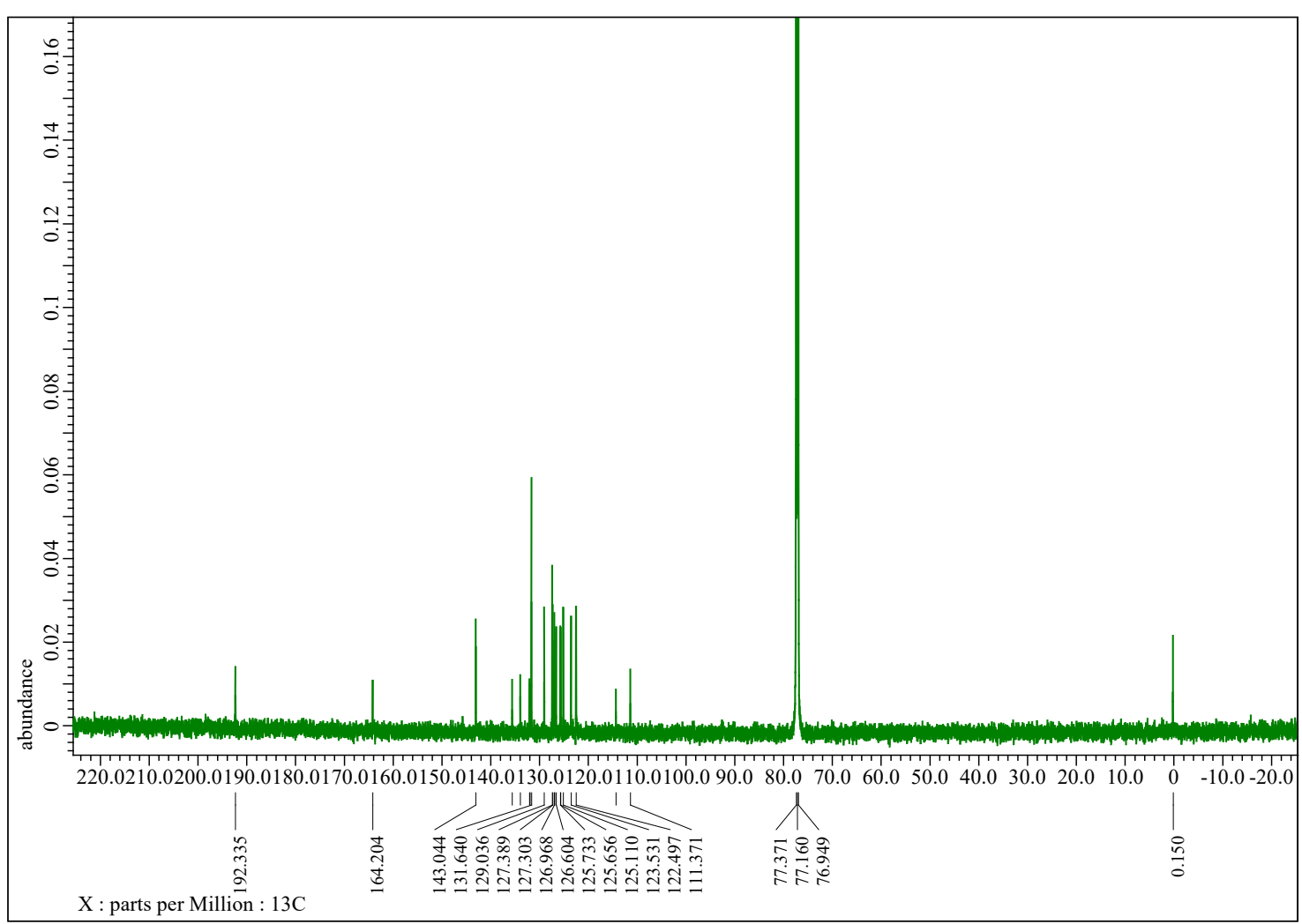


Figure S9. ${ }^{1} \mathrm{H}$ NMR spectrum of compound $10\left(400 \mathrm{MHz}\right.$, in $\left.\mathrm{CDCl}_{3}\right)$

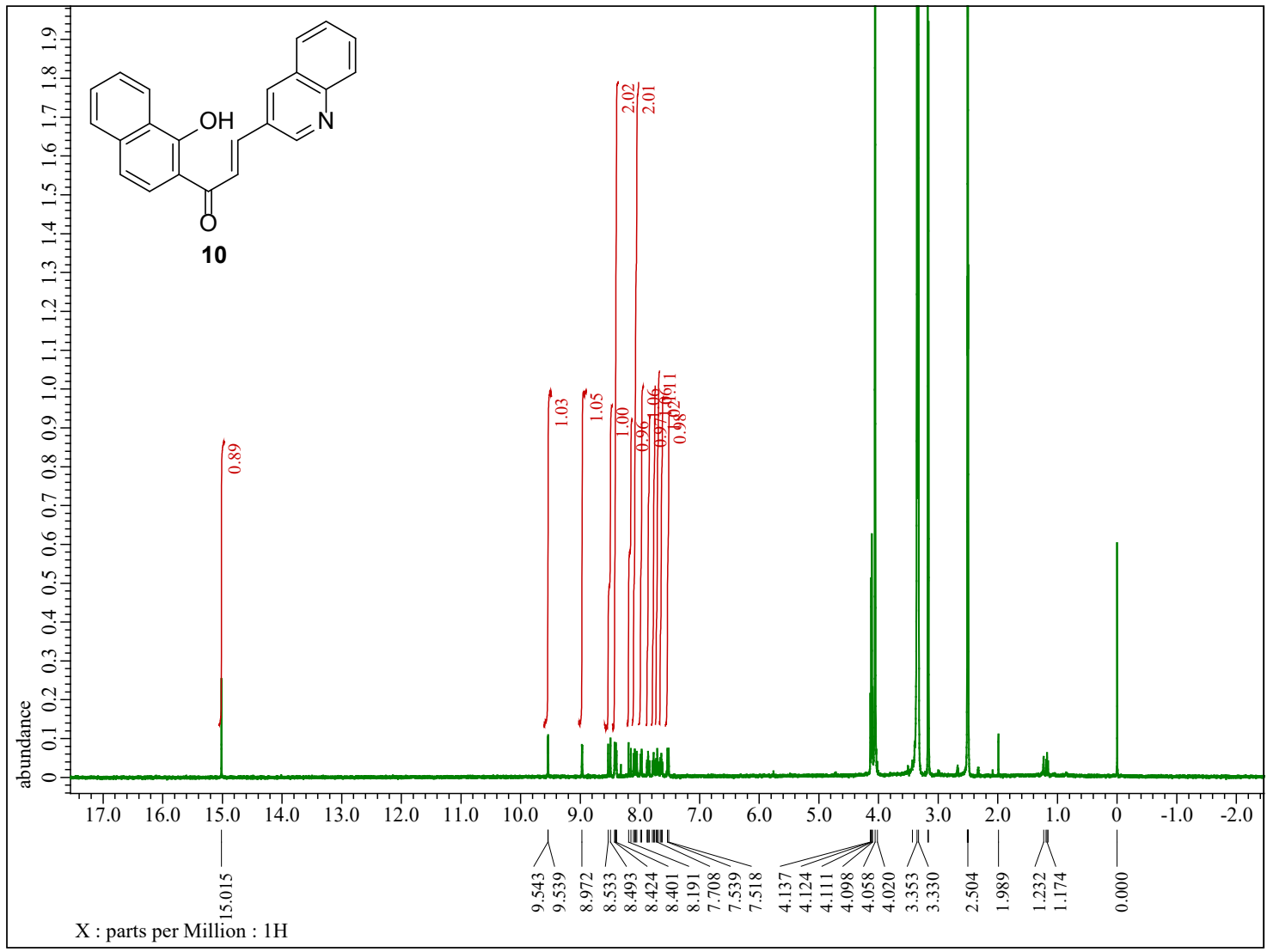

${ }^{13} \mathrm{C}$ NMR of $\mathbf{1 0}$ was not able to record due to the low solubility to any organic solvent. 
Figure S10. ${ }^{1} \mathrm{H}$ NMR spectrum of compound $11\left(600 \mathrm{MHz}\right.$, in $\left.\mathrm{CDCl}_{3}\right)$

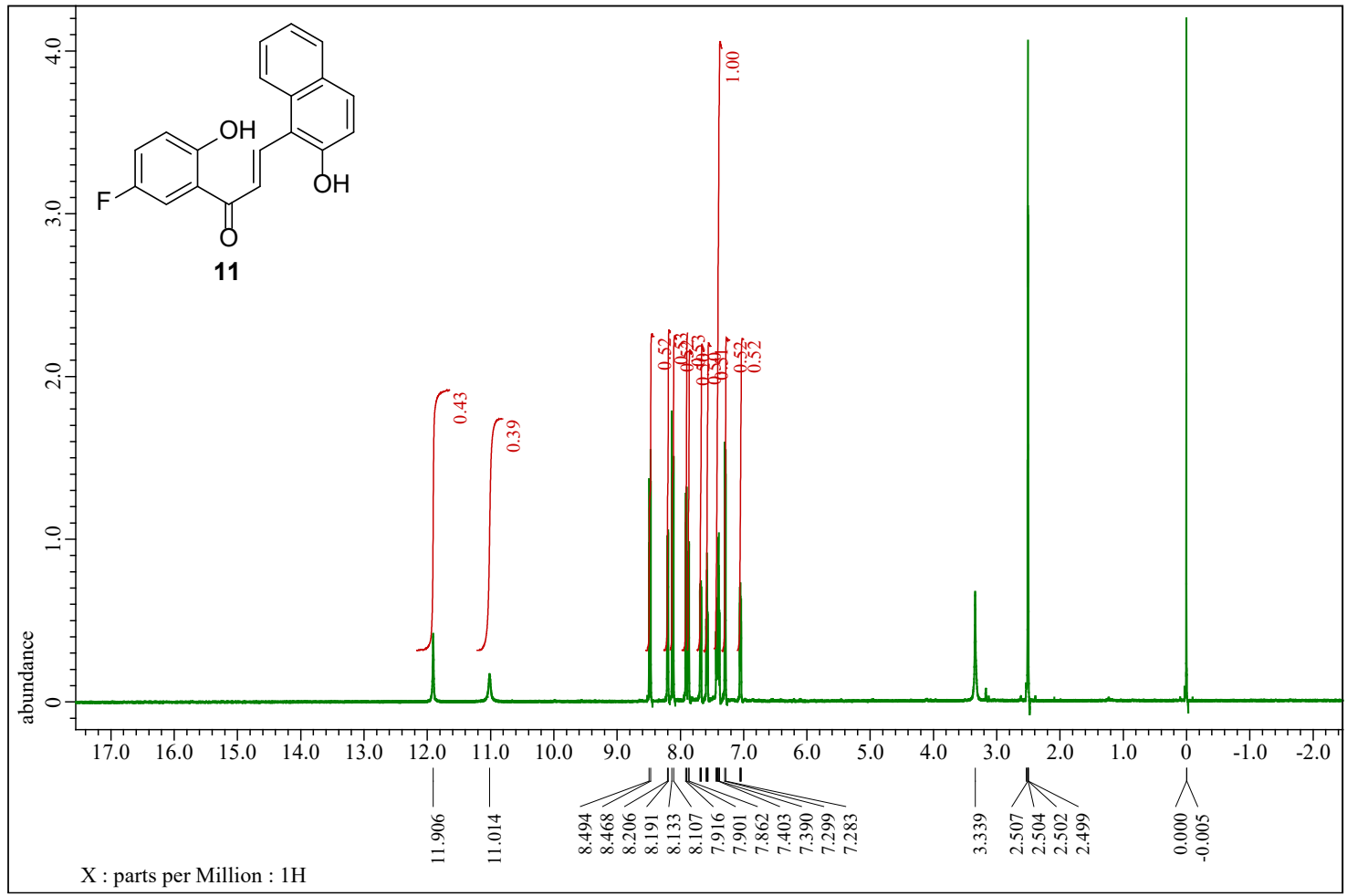

Figure S11. ${ }^{13} \mathrm{C}$ NMR spectrum of compound $11\left(150 \mathrm{MHz}\right.$, in $\left.\mathrm{CDCl}_{3}\right)$

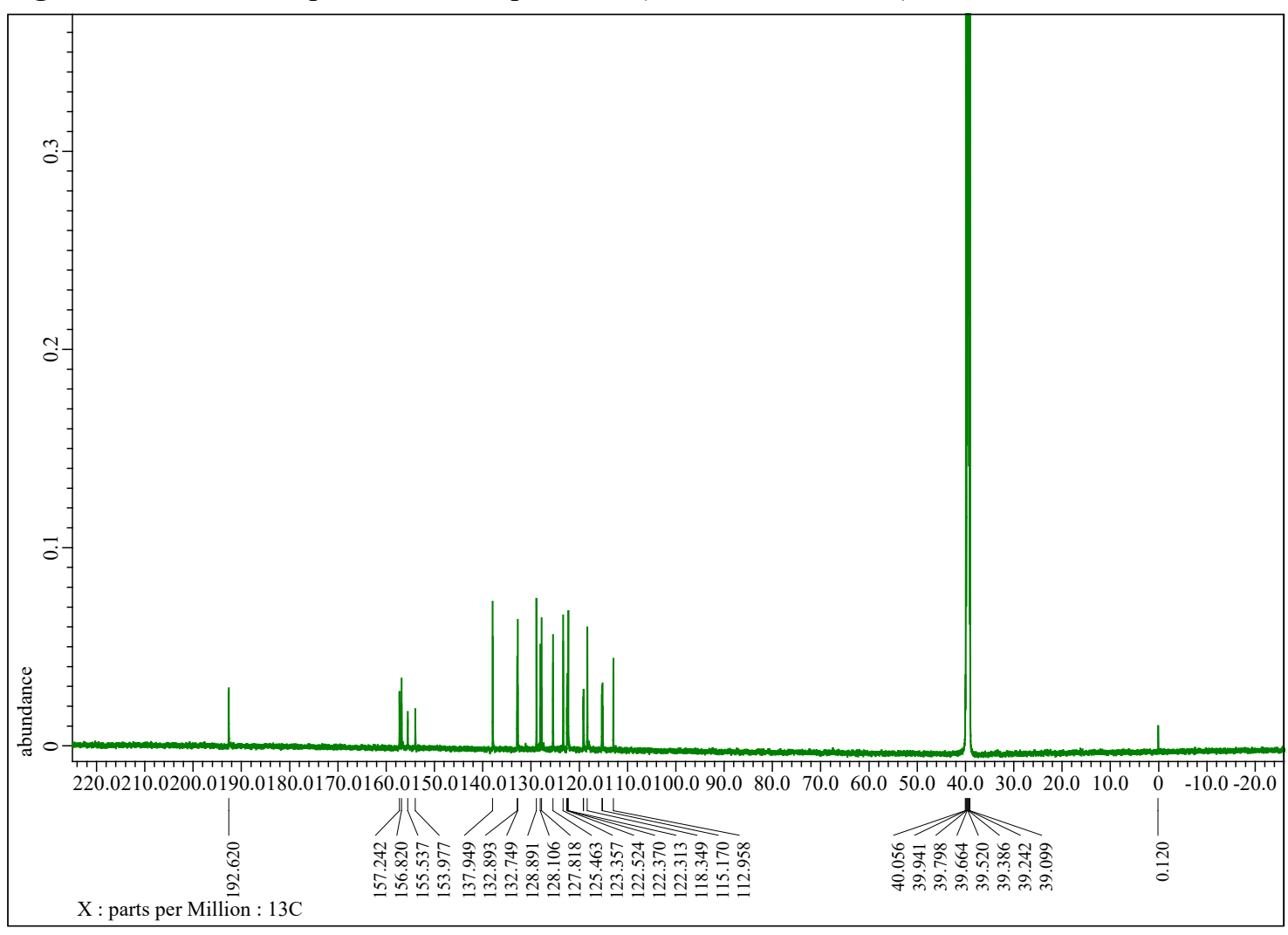


Figure S12. ${ }^{1} \mathrm{H}$ NMR spectrum of compound $12\left(600 \mathrm{MHz}\right.$, in $\left.\mathrm{CDCl}_{3}\right)$

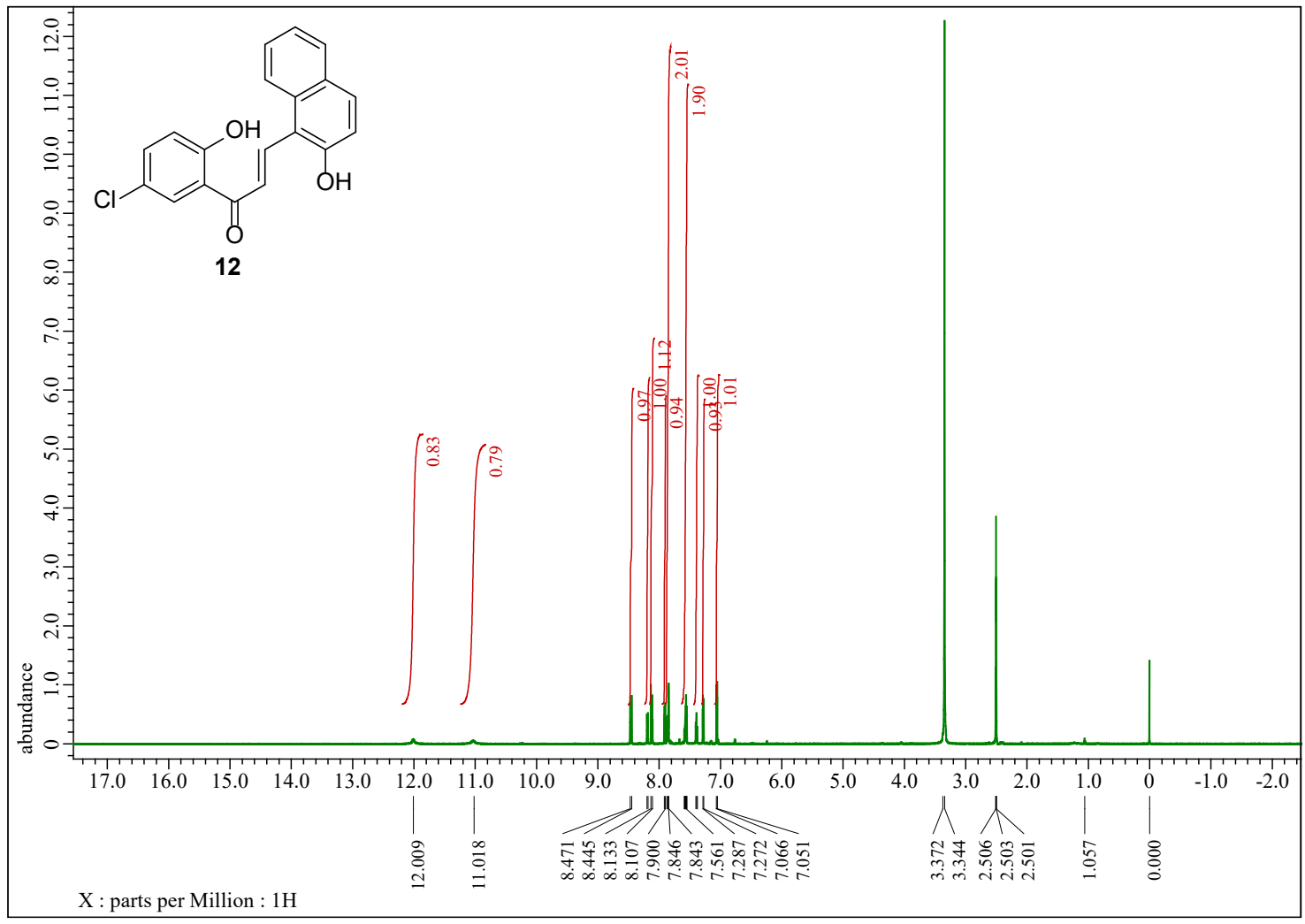

Figure S13. ${ }^{13} \mathrm{C}$ NMR spectrum of compound $12\left(150 \mathrm{MHz}\right.$, in $\left.\mathrm{CDCl}_{3}\right)$

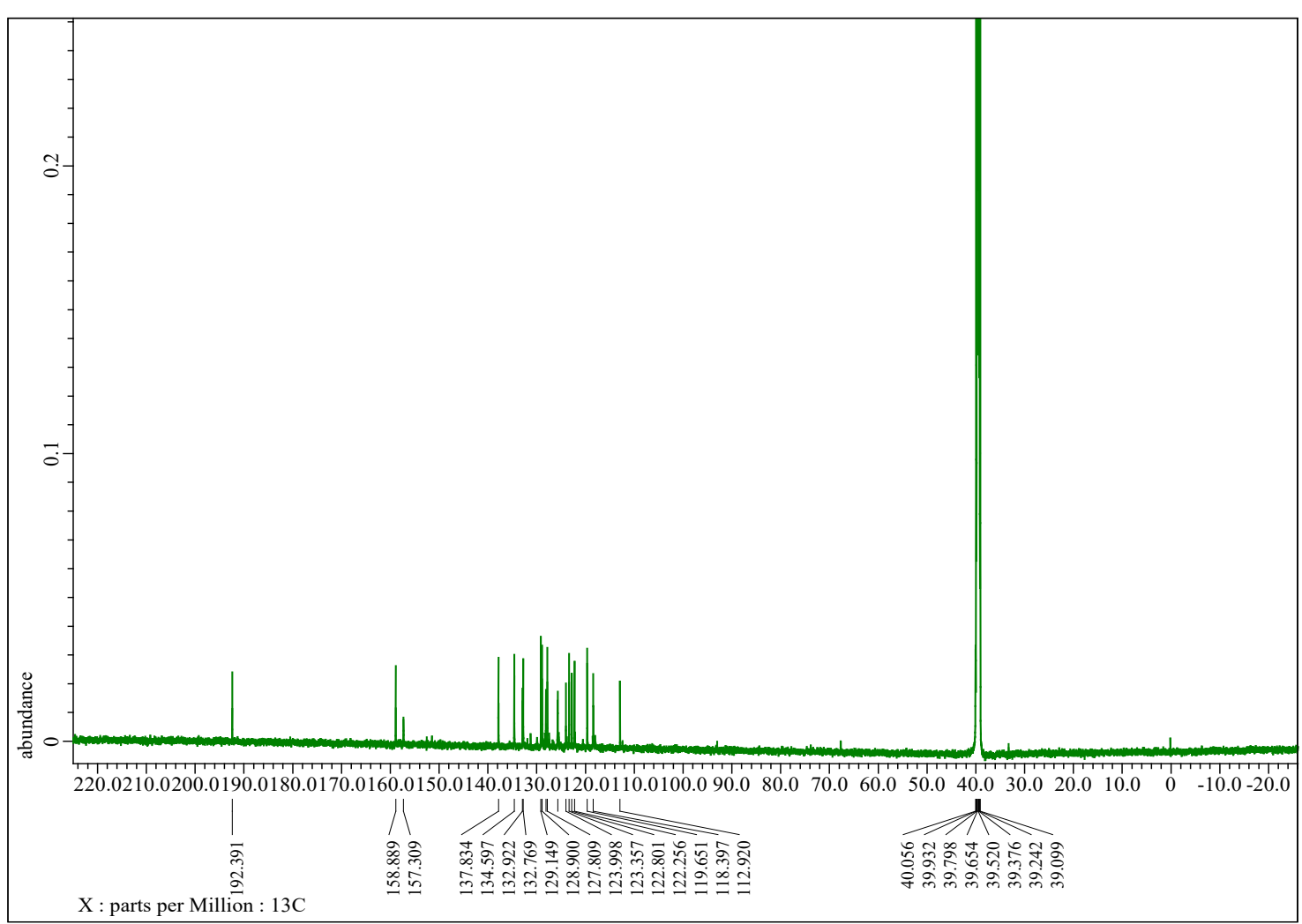


Figure S14. ${ }^{1} \mathrm{H}$ NMR spectrum of compound $13\left(400 \mathrm{MHz}\right.$, in $\left.\mathrm{CDCl}_{3}\right)$

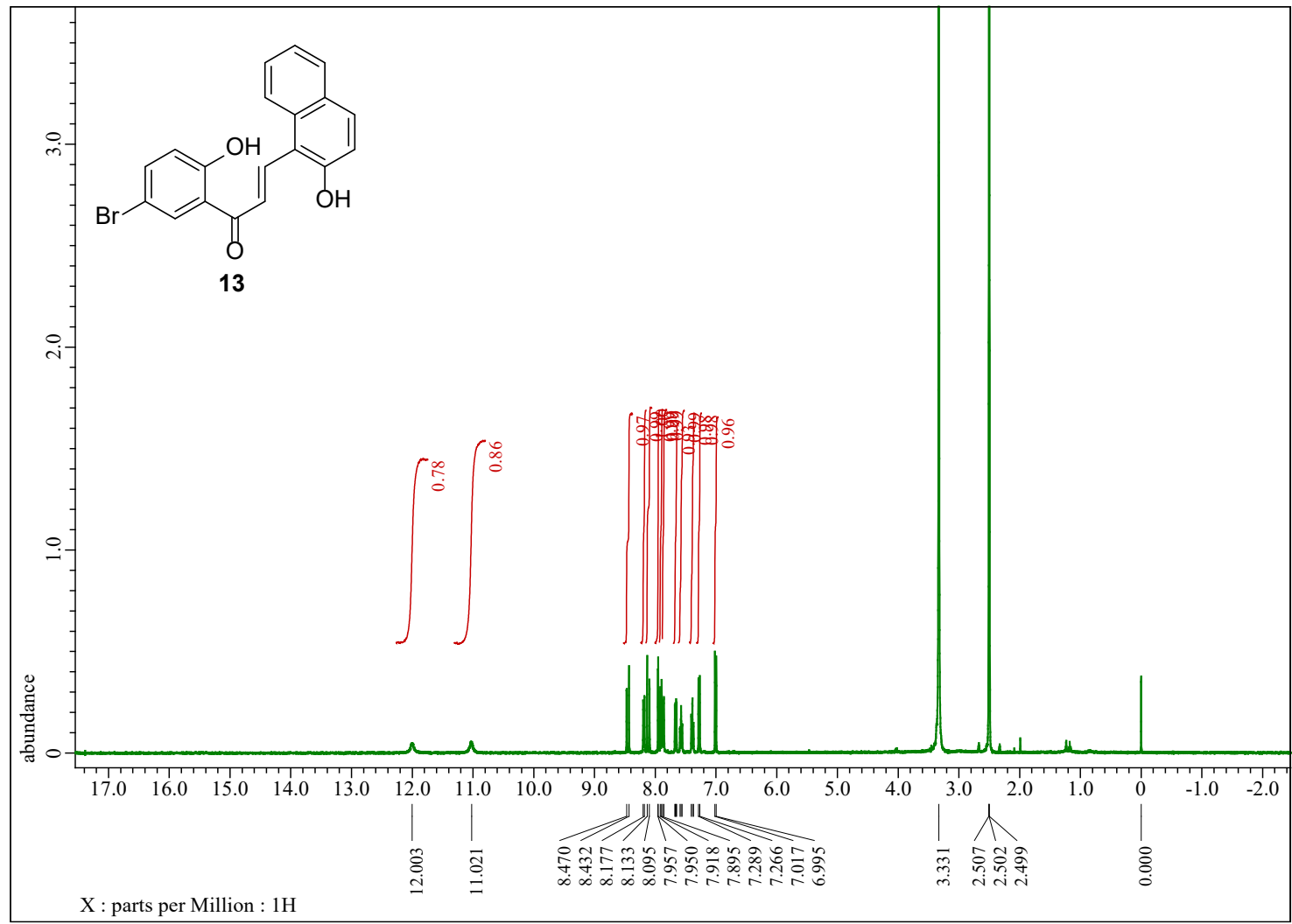

Figure S15. ${ }^{13} \mathrm{C}$ NMR spectrum of compound $13\left(150 \mathrm{MHz}\right.$, in $\left.\mathrm{CDCl}_{3}\right)$

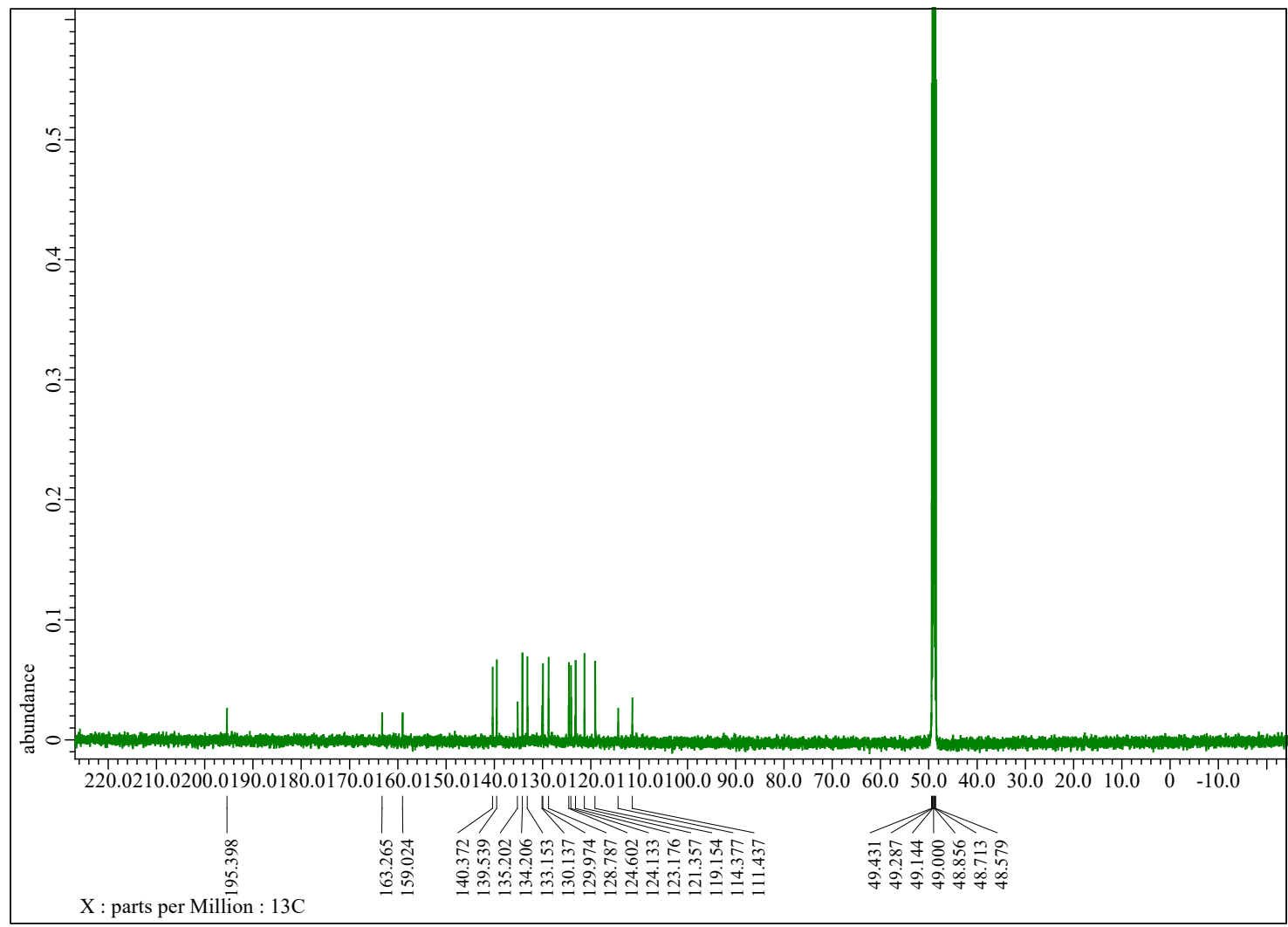


Figure S16. ${ }^{1} \mathrm{H}$ NMR spectrum of compound $14\left(400 \mathrm{MHz}\right.$, in $\left.\mathrm{CDCl}_{3}\right)$

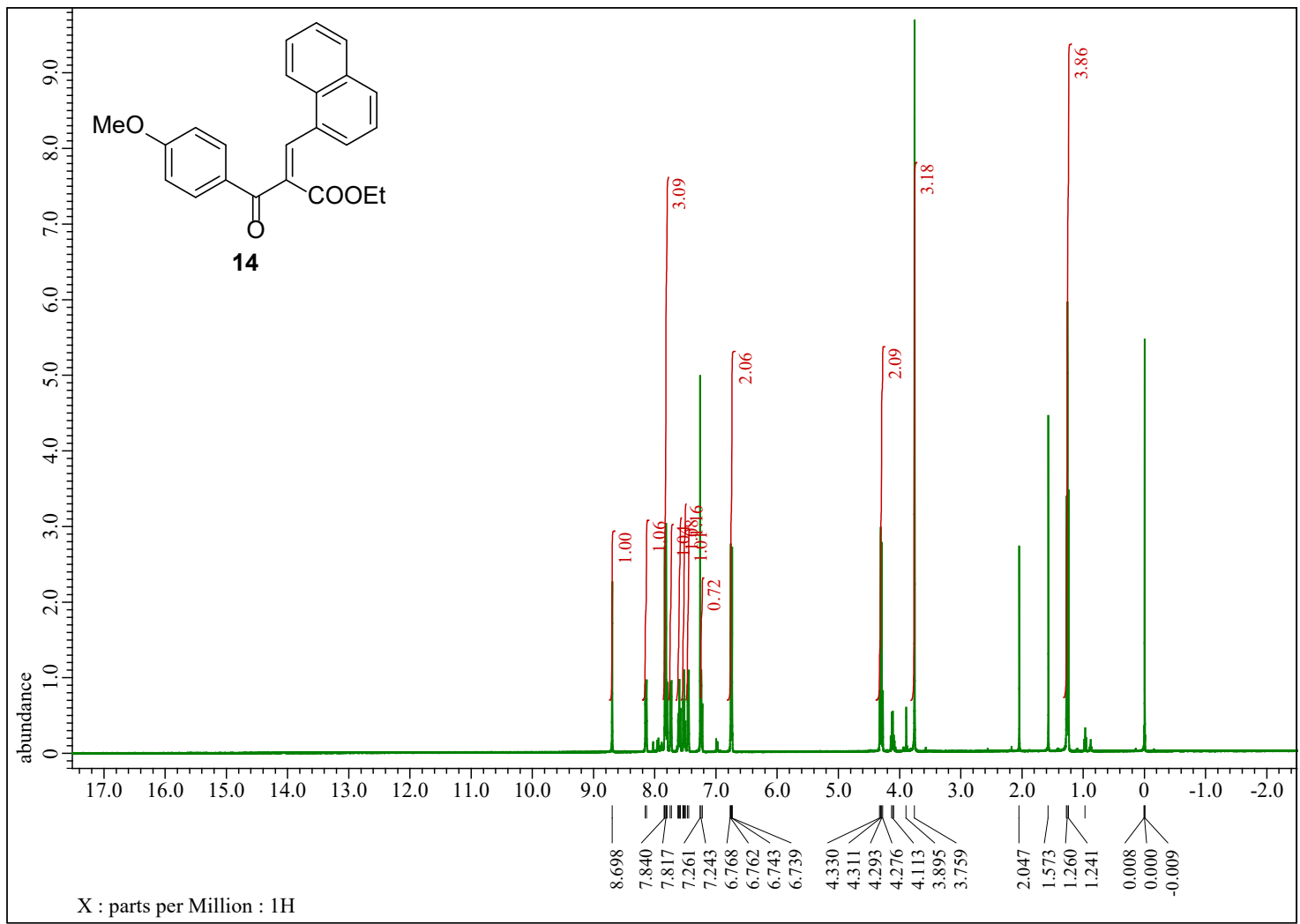

Figure S17. ${ }^{13} \mathrm{C}$ NMR spectrum of compound $14\left(150 \mathrm{MHz}\right.$, in $\left.\mathrm{CDCl}_{3}\right)$

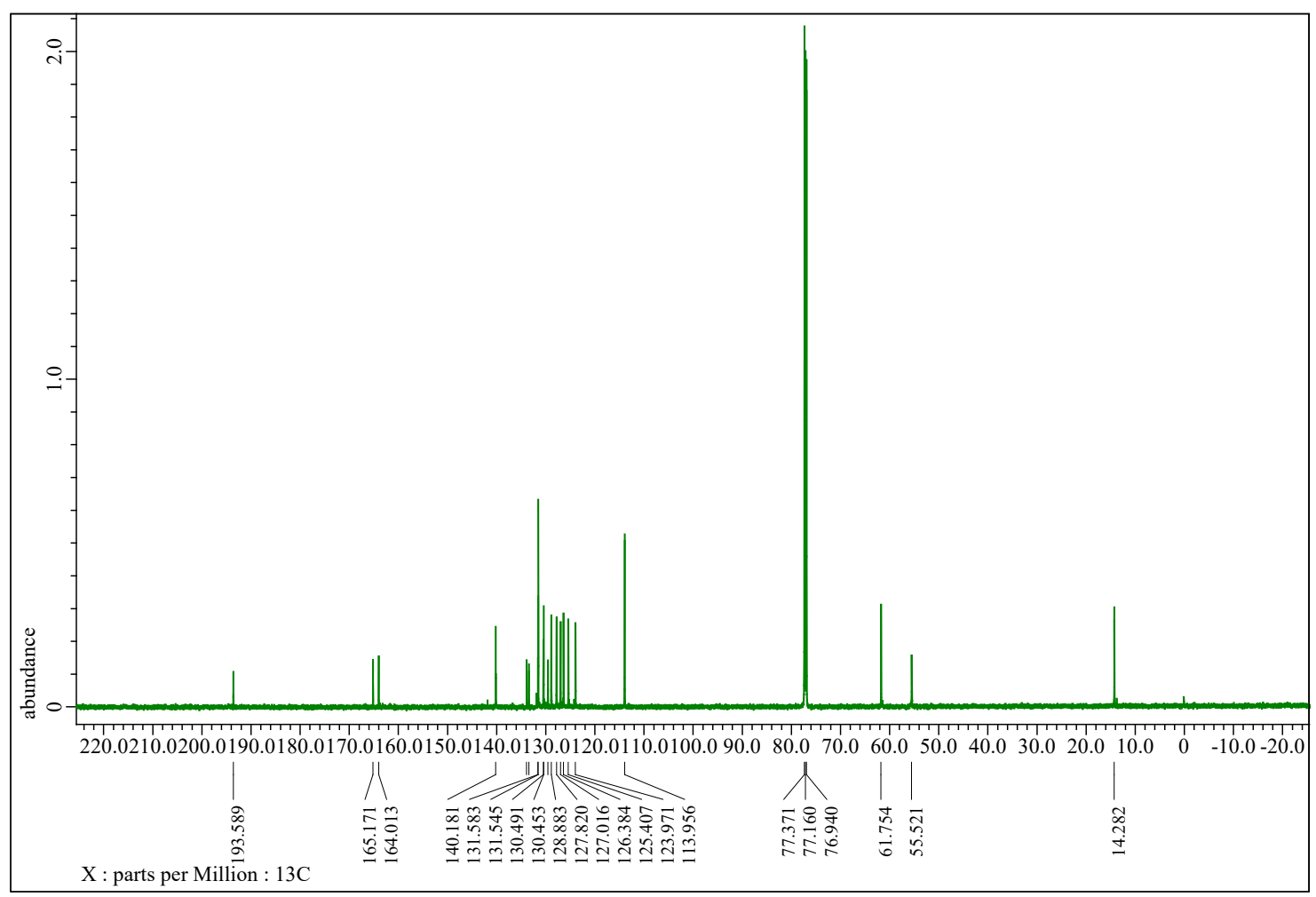


Figure S18. ${ }^{1} \mathrm{H}$ NMR spectrum of compound $15\left(400 \mathrm{MHz}\right.$, in $\left.\mathrm{CDCl}_{3}\right)$

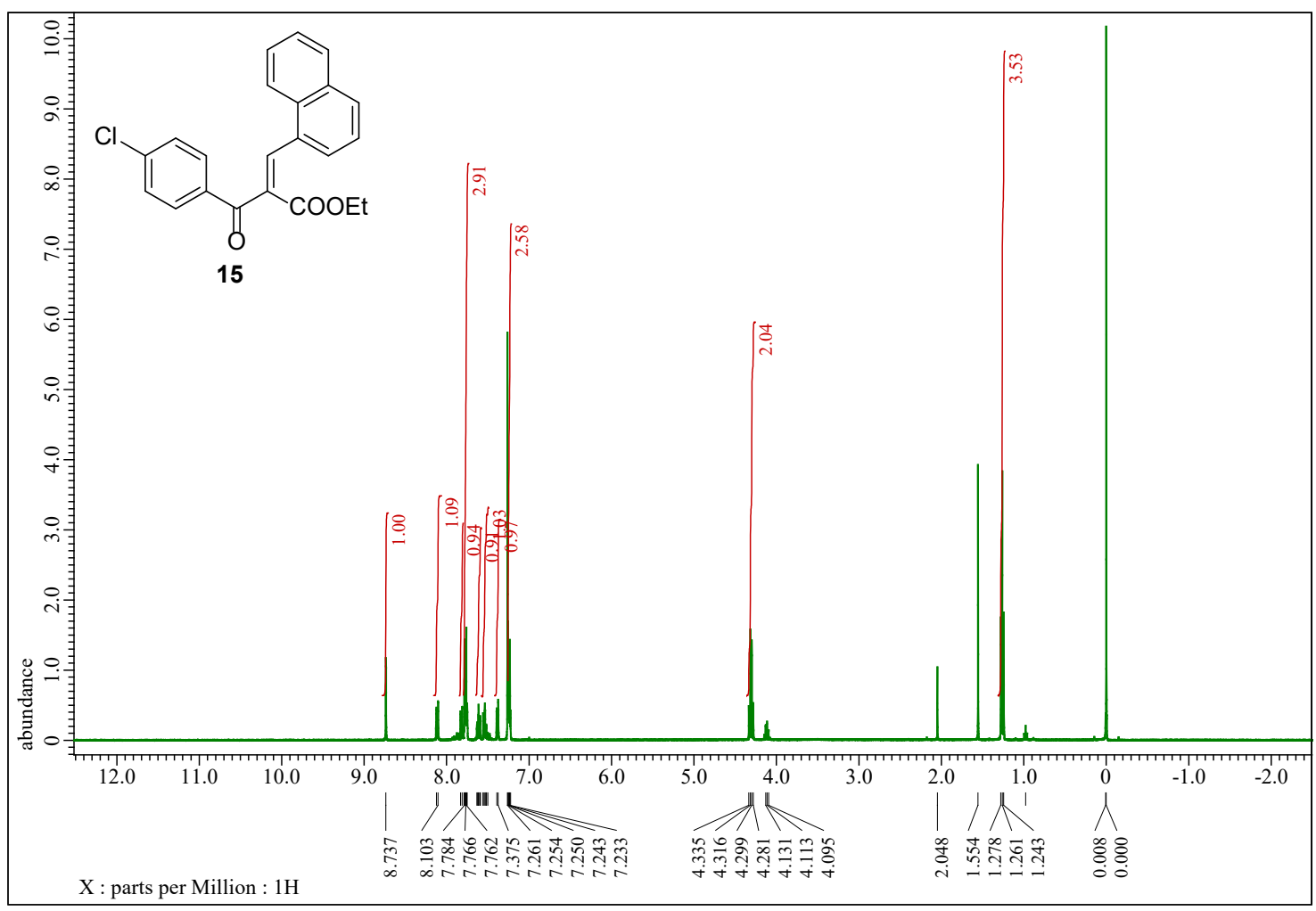

Figure S19. ${ }^{13} \mathrm{C}$ NMR spectrum of compound $15\left(150 \mathrm{MHz}\right.$, in $\left.\mathrm{CDCl}_{3}\right)$

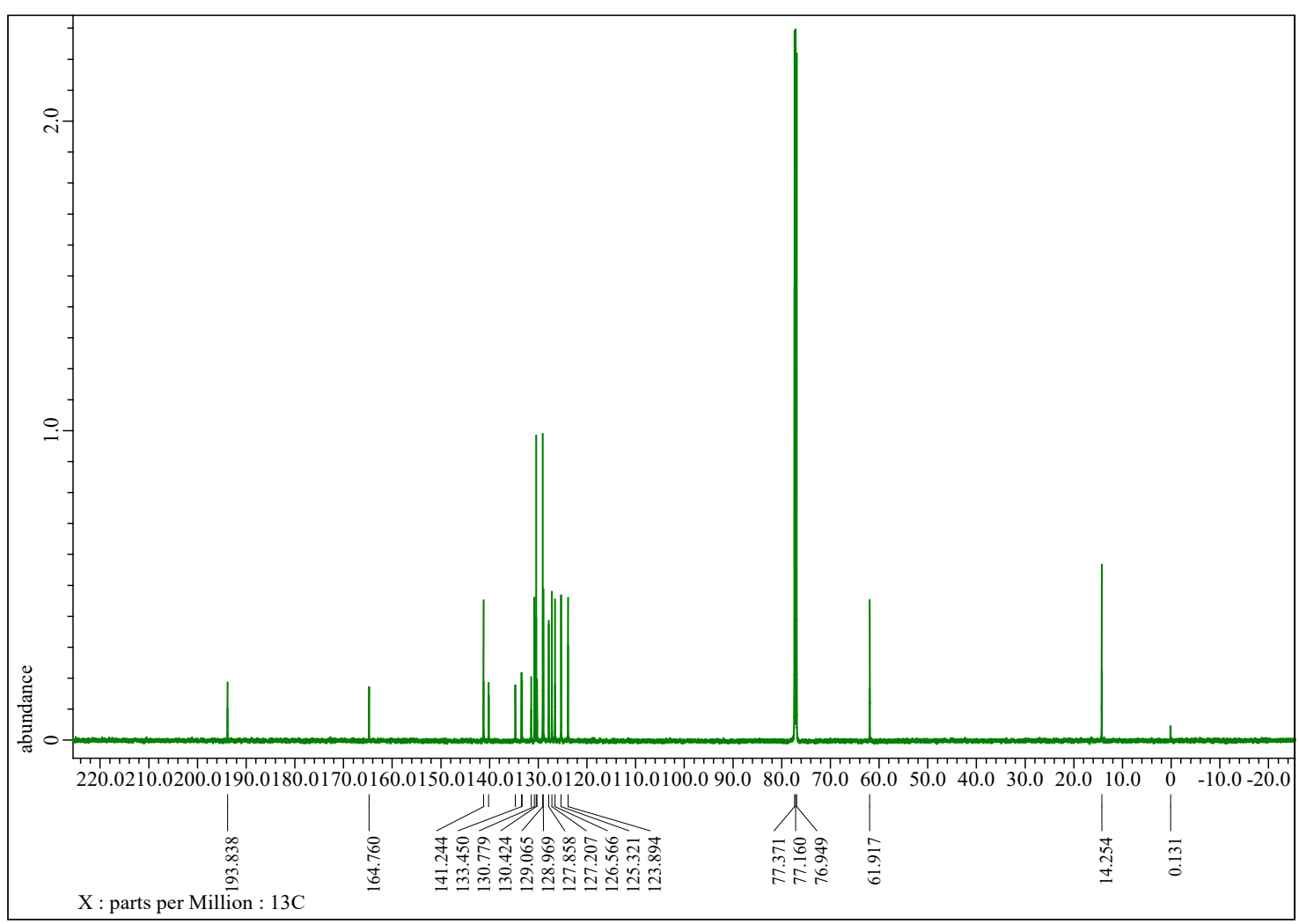

